\title{
FENOMENA POLISEMIK BAHASA ARAB DALAM AL-QUR'AN DAN IMPLIKASI PEMBELAJARANNYA
}

\author{
Wagino Hamid Hamdani \\ Maman Abdurrahman \\ Jurusan Pendidikan Bahasa Arab FPBS UPI \\ Korespondensi: Jln. Dr. Setiabudhi 229 Bandung 40154 Jawa Barat \\ Pos-el: hwagino@yahoo.com
}

\begin{abstract}
Abstrak
Penelitian ini bertujuan mengungkap ihwal polisemi bahasa Arab dalam Alquran dan variasi makna leksikal-gramatikalnya. Hasil penelitian yang

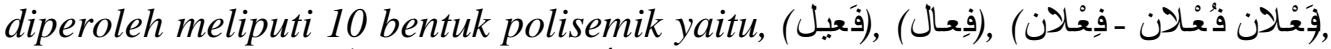

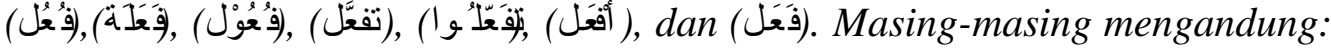
4 (empat) makna morfologis; 3 (tiga) makna morfologis; 4 (empat) makna morfologis; 3 (tiga) makna morfologis; 4 (lima) makna morfologis; 3 (tiga) makna morfologis; 2 (dua) makna morfologis; 4 (empat) makna morfologis; 5 (empat) makna morfologis; 5 (lima) makna morfologis. Munculnya bentuk polisemik bahasa Arab dalam Alquran karena (1) proses morfofonemis yang berkaitan dengan penerapan hadzf, ta mudhara'ah, (2) proses morfologis meliputi morf, morfem, tauzi' sharfy, dan tahlil dakhili lil kalimah, dan (3) proses morfosintaktis yang meliputi tauzi'sharfy-tarkiby, tarkib idhafi, dan tarkib 'adadi. Pada umumnya (61,38\%), bentuk polisemik bahasa Arab dalam Alquran memiliki tingkat variasi leksikal/gramatikal yang mencakup repetitif $(33,83 \%)$, sinonim $(11,11 \%)$, polisemik $(6,80 \%)$, dan gramatikal $(9,50)$. Selain

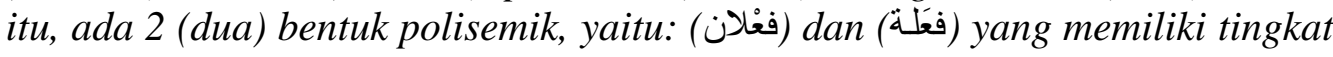
variasi leksikal/gramatikal dalam kategori tinggi (77,78\%) dan (72,00\%);

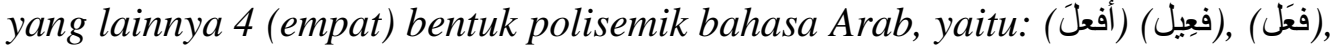
dan (فُول) memiliki tingkat variasi leksikal/gramatikal dalam kategori sedang (masing-masing secara berurutan: (63,81\%), (66,04\%), 68,52\%), dan $(69,87 \%)$.
\end{abstract}

Kata -Kata Kunci: Polisemi, makna leksikal-gramatikal/morfologis 


\begin{abstract}
This study aims to reveal the Arabic polysemy in the Koran and its variation of lexico-grammatical meaning. Ten forms of polysemy were obtained, namely,

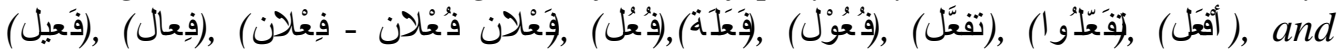
(فَ). Each contains four morphological meanings, three morphological meanings, four morphological meanings, three morphological meanings, five morphological meanings, three morphological meanings, two morphological meanings, four morphological meanings, four morphological meanings, and five morphological meanings, respectively. The appearance of the Arabic polysemy in the Koran is attributed to (i) the process associated with the application of morphophonemic hadzf, ta mudhara'ah, (ii) the morphological process which includes morf, morfem, tauzi' sharfy, and tahlil dakhili lil kalimah, and (iii) the morphosyntactic process which includes tauzi' sharfytarkiby, tarkib idhafi, and tarkib 'adadi. In general (61.38\%), the Arabic polysemic forms in the Koran have lexico-grammatical variations including repetitive (33.83\%), synonyms (11.11\%), polisemic $(6.80 \%)$, and grammatical

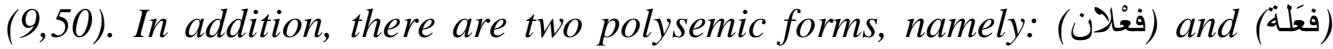
which have a lexical-grammatical variety in the high category (77.78\%) and

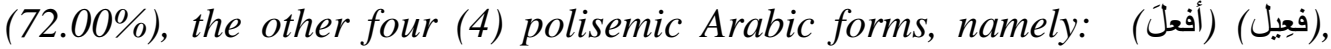
(فعَ) have high levels of lexico-grammatical variation in the medium category: (63.81\%), (66.04\%), (68.52\%) and (69.87\%), respectively.
\end{abstract}

Key Words : Polysemy, lexico-grammatical/morphological meanings

\section{PENDAHULUAN}

Bahasa tersusun dari sejumlah unsur yang menyangkut bentuk dan makna. Bentuk bahasa adalah struktur bahasa yang meliputi aspek fonologi, morfologi, sintaksis, dan semantik. Berkaitan dengan struktur bahasa, kaidah-kaidah morfologi bahasa Arab mudah dicerna dan dihafal karena setiap kata memiliki wazan (pola) tersendiri dengan jumlah wazan terbatas, yaitu kurang lebih 30 wazan. Namun dalam aplikasinya ia memerlukan dukungan dan kaitan sintaktis serta makna leksikal. Hal ini karena sistem morfologi bahasa Arab mengandung bentuk-bentuk homograf dan bentuk-bentuk polisemik. Misalnya, lambang tulisan علم sulit ditentukan bentuk, kategori dan makna morfologisnya apabila kata tersebut berada di luar konteks kalimat atau di luar kaitan sintaktis.

علم Secara morfologis, lambang mengandung kemungkinan baca dan bentuk yang beraneka ragam sesuai

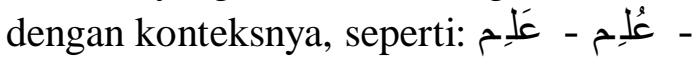

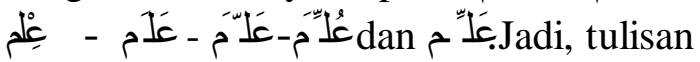
bahasa Arab tidak dapat dibaca sebelum kita memahami makna dan hubungan antarkata dalam kalimat. Kesalahan morfologis dalam menentukan bentuk, wazan, atau pola kata yang terjadi di kalangan mahasiswa tingkat pemula, bahkan mahasiswa tingkat akhir sering diakibatkan oleh munculnya bentuk polisemik. Misalnya, kata تَلَ ) تفرقوا

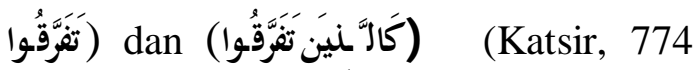
H:91) yang berwazan تفعلـوا dapat 
mengandung 4 makna atau kategori morfologis, yaitu (1) makna fi'il madhi (verba lampau), (2) fi'il mudhari (verba kini/keakanan), (3) fi'il amr (verba suruh), dan (4) fi'il nahyi (verba larang). Makna morfologis yang mana yang dimaksud dengan kata itu tergantung kepada konteks kalimat atau kaitan sintaktis.

Ada lima bentuk kata dalam bahasa Arab yang mengandung makna morfologis ganda, yaitu (1) fa'il dapat berkategori isim fa'il dari fa'ala dan kategori fi'il amr, (2) $f a^{\prime} l$ dapat berkategori mashdar (gerund) dan sifat musyabbahah (adjektiva), (3) fi'il mudhari dapat disandarkan kepada dhamir mukhathab dan dhamir ghaibah, (4) tafa'laa dapat menunjukkan fi'il madhi, fi'il mudhari dan fi'il amr, dan (5) tafa'la dapat menunjukkan fi'il madhi, dan fi'il mudhari (Periksa Hassan, 1979:150).

Sekaitan dengan itu, Mubarak (1960: 137-138) mengemukakan bahwa satu wazan dalam bahasa Arab bisa saja menunjukkan makna ganda. Misalnya, wazan fa'iil (فعيل) bisa menunjukkan (1) sifat tetap, seperti: ( - كريم - شـريف (1) - (1)

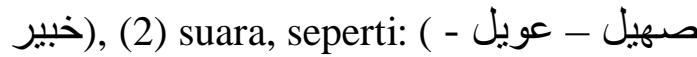
زئير). Wazan fi'aal bisa menunjukkan (1) bentuk mashdar dari faa'ala yufaa'ilu seperti: (قتال - سباق), (2) perkakas dan peralatan, seperti: ( إنـاء - (2) حز), dan (3) bentuk jamak dari bentuk fa'iil, seperti (كر ام - لنئام - طوال). Wazan af'ala bisa menunjukkan (1) bentuk fi' il muta'addi (verba transitif) dari fi'il

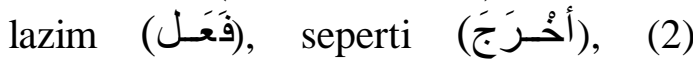
mendapati sifat, seperti ( أحمده =وجده (2) حميدا), dan (3) mencapai sesuatu (tiba

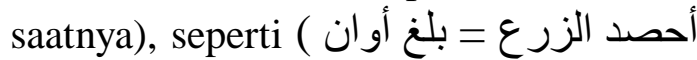
(حصاده).
Kemudian penelitian ini mengacu pada konsep morfoleksikal yang mencakup leksikal dan makna gramatikal. Makna leksikal makna kata atau leksem sebagai lambang benda, peristiwa, obyek, dan lain-lain. Makna gramatikal adalah makna yang muncul sebagai akibat hubungan antara unsurunsur gramatikal dalam satuan gramatikal yang lebih besar (http://id.wikipedia.org/wiki/ Makna).

Selanjutnya dikemukakan bahwa untuk mencapai makna secara komprehensif kita harus menggunakan teknik analisis dalam kajian bahasa, yaitu (1) shauti (fonologi), (2) sharf (morfologi), (3) nahwu (sintaksis), dan (4) mu'jam (leksikon), yaitu yang berkaitan dengan makna leksikal (Hassan, 1979:341). Adapun aspek kajian sharf adalah morfem yaitu satuan bahasa terkecil yang mengandung makna (Syahin, 1980:114); satuan terkecil dalam analisis sintaktis (Hasanain, 1984:149); dan satuan bahasa yang paling kecil yang memiliki makna atau fungsi morfologis dalam salah satu bahasa (Hanna, 1997: 89).

Untuk mengidentifikasi, mengklasifikasi dan menganalisis bentuk polisemik bahasa Arab, dapat digunakan dua kriteria, yaitu (1) konteks atau distribusi sintaktis dan (2) distribusi morfologis dengan mengacu pada tabel infleksi (jadwal tashrif) yang didukung oleh pengenalan makna leksikalnya. Oleh karena itu, ada 3 (tiga) konsep yang harus dijadikan acuan dalam memahami dan menerapkan serta menganalisis bentuk polisemik dan makna leksikalgramatikal, yaitu (1) morfofonemik, (2) morfosintaksis, dan (3) morfo-leksikal.

Sejauh ini, bentuk kepolisemikan bahasa Arab belum terdeskripsikan baik dari segi frekuensi pemakaiannya maupun makna morfologisnya. Oleh 
karena itu, tulisan ini bertujuan mendeskripsikan bentuk-bentuk polisemik bahasa Arab dan makna leksikal-gramatikalnya.

\section{METODE}

Penelitian ini dilakukan dengan menggunakan metode deskriptif dengan model analisis isi. Adapun yang menjadi sumber datanya adalah sejumlah kata bahasa Arab yang berwazan atau berpola polisemik (sebanyak 10 bentuk polisemik yang terdapat dan tersebar di semua ayat Alquran. Selanjutnya data penelitian dikumpulkan melalui dokumentasi tertulis (mushaf Alquran) dan pedoman pencatatan data. Kemudian data tersebut dianalisis secara (1) kualitatif (analisis morfosintaktisleksikal) untuk mengkaji makna morfologis dan variasi makna leksikalgramatikal setiap bentuk polisemik dan (2) kuantitatif untuk menghitung frekuensi pemakaiannya.

\section{HASIL DAN PEMBAHASAN}

Secara umum tingkat variasi makna leksikal-gramatikal dalam bahasa Indonesia terjemahan Alquran dapat dilihat pada Tabel 1 di bawah ini.

Tabel 1

Tingkat Variasi Makna Lekssikal-Gramatikal

\begin{tabular}{|c|c|c|c|}
\hline \multirow[t]{2}{*}{ No. } & \multirow[t]{2}{*}{ Bentuk Polisemik } & \multicolumn{2}{|c|}{ Tingkat Variasi Makna Leksikal } \\
\hline & & Bervariasi (\%) & Tidak Bervariasi (\%) \\
\hline 1 & فعِيل (159x) & $105(66,04)$ & $54(35,96)$ \\
\hline 2 & فِّعال (105x) & $56(53.33)$ & $49(46,67)$ \\
\hline 3 & (54x) فْغْلنن & $42(\mathbf{7 7 , 7 8})$ & $12(22,22)$ \\
\hline 4 & (46x) فُعل & $20(43,48)$ & $26(56,52)$ \\
\hline 5 & فعَلة & $18(\mathbf{7 2 , 0 0})$ & $7(28,00)$ \\
\hline 6 & (73x) فُعُول (13x) & $51(\mathbf{6 9 , 8 7})$ & $22(30,13)$ \\
\hline 7 & تفعُّلَ (29x) & $13(44,82)$ & $16(55,18)$ \\
\hline 8 & تفعُلو ا & $13(54,17)$ & $11(45,83)$ \\
\hline 9 & (105x) أفَعَلَ & $67(\mathbf{6 3 , 8 1})$ & $38(36,19)$ \\
\hline 10 & (108x) & $74(\mathbf{6 8 , 5 2})$ & $34(31,48)$ \\
\hline & Rerata & 61,38 & 38,62 \\
\hline
\end{tabular}

Adapun secara rinci, tingkat variasi leksikal-gramatikal bentuk polisemik bahasa Arab dalam Alquran tampak pada tabel berikut. 
Tabel 2

Tingkat Variasi Leksikal-Gramatikal

\begin{tabular}{|c|c|c|c|c|c|c|}
\hline \multirow[b]{2}{*}{ No. } & \multirow[b]{2}{*}{$\begin{array}{c}\text { Bentuk } \\
\text { Polisemik }\end{array}$} & \multirow[b]{2}{*}{ Jumlah } & \multicolumn{4}{|c|}{ Tingkat Variasi Leksikal-Gramatikal } \\
\hline & & & Repetitif & Sinonim & Polisemik & Gramatikal \\
\hline 1 & فِيل & 159 & $\begin{array}{c}65 \\
(40,89 \%) \\
\end{array}$ & $\begin{array}{c}9 \\
(5,56 \%) \\
\end{array}$ & $\begin{array}{c}9 \\
(5,56 \%)\end{array}$ & $\begin{array}{c}22 \\
(13,84 \%)\end{array}$ \\
\hline 2 & فِعِعال & 105 & $\begin{array}{c}31 \\
(29,52 \%)\end{array}$ & $\begin{array}{c}14 \\
(13,33 \%)\end{array}$ & $\begin{array}{c}4 \\
(3,81 \%)\end{array}$ & $\begin{array}{c}7 \\
(6,67 \%)\end{array}$ \\
\hline 3 & فَعلان & 54 & $\begin{array}{c}26 \\
(48,15 \%)\end{array}$ & $\begin{array}{c}6 \\
(11,11 \%)\end{array}$ & $\begin{array}{c}3 \\
(5,56 \%)\end{array}$ & $\begin{array}{c}7 \\
(12,96 \%)\end{array}$ \\
\hline 4 & فَعُل & 46 & $\begin{array}{c}13 \\
(28,26 \%)\end{array}$ & $\begin{array}{c}3 \\
(6,52 \%)\end{array}$ & $\begin{array}{c}1 \\
(2,17 \%)\end{array}$ & $\begin{array}{c}3 \\
(6,52 \%)\end{array}$ \\
\hline 5 & فَعَلة & 25 & $\begin{array}{c}10 \\
(40,00 \%)\end{array}$ & $\begin{array}{c}4 \\
(16,00 \%)\end{array}$ & $\begin{array}{c}1 \\
(4 \%)\end{array}$ & $\begin{array}{c}3 \\
(12 \%)\end{array}$ \\
\hline 6 & فُعُول & 73 & $\begin{array}{c}25 \\
(34,25 \%)\end{array}$ & $\begin{array}{c}9 \\
(12,33 \%)\end{array}$ & $\begin{array}{c}4 \\
(5,48 \%)\end{array}$ & $\begin{array}{c}13 \\
(17,81 \%)\end{array}$ \\
\hline 7 & تفعُّلَ & 29 & $\begin{array}{c}5 \\
(17,24 \%)\end{array}$ & $\begin{array}{c}4 \\
(13,79 \%)\end{array}$ & $\begin{array}{c}3 \\
(10,34 \%)\end{array}$ & $\begin{array}{c}1 \\
(3,45 \%)\end{array}$ \\
\hline 8 & تفعُلو ا & 24 & $\begin{array}{c}8 \\
(33,33 \%) \\
\end{array}$ & $\begin{array}{c}4 \\
(16,67 \%) \\
\end{array}$ & $\begin{array}{c}1 \\
(4,17 \%) \\
\end{array}$ & $\begin{array}{c}- \\
(0,00) \\
\end{array}$ \\
\hline 9 & أفعلَ & 105 & $\begin{array}{c}34 \\
(32,38 \%)\end{array}$ & $\begin{array}{c}2 \\
(1,90 \%)\end{array}$ & $\begin{array}{c}15 \\
(14,29 \%)\end{array}$ & $\begin{array}{c}16 \\
(15,24 \%)\end{array}$ \\
\hline 10 & فَعَل & 108 & $\begin{array}{c}37 \\
(34,26 \%) \\
\end{array}$ & $\begin{array}{c}15 \\
(13,89 \%) \\
\end{array}$ & $\begin{array}{c}15 \\
(13,89 \%) \\
\end{array}$ & $\begin{array}{c}7 \\
(6,48 \%) \\
\end{array}$ \\
\hline & Rerata & & $(33,83 \%)$ & $(11,11 \%)$ & $(6,80 \%)$ & $(9,50 \%)$ \\
\hline
\end{tabular}

Pada bagian sebelumnya telah dikemukakan 6 (enam) rumusan masalah penelitian yang mempermasalahkan bagaimana 6 (enam) aspek, yaitu: (1) pola polisemi, (2) proses morfofonemis, (3) proses morfologis, (4) proses morfosintaksis polisemi bahasa Arab dalam Alquran, (5) variasi makna leksikalnya, dan (6) implikasi pembelajarannya.

Keenam aspek masalah penelitian dapat dijawab dengan hasil penelitian sebagai berikut.

Pola (wazan) polisemi bahasa

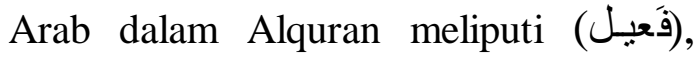

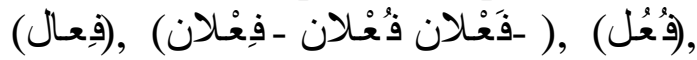

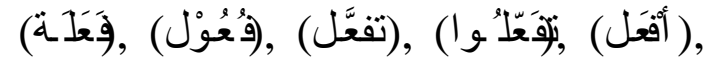
dan (فَعَ).

Pola pertama fa'il (فَعَبــل mengandung 4 (empat) makna morfologis, yaitu: sifat, isim, jamak, dan

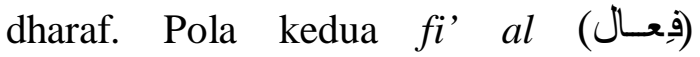
mengandung 3 (tiga) makna morfolosis, yaitu: mufrad, jamak, dan sifat. Pola ketiga fa'lan/fi'lan/fu'lan ( فَعْلان فُعْلان فَفْْنلان-) mengandung 4 (empat) makna morfologis, yaitu: mufrad, mutsanna, jamak, dan sifat. Pola keempat fu'ul (فُ فُحُل mengandung 3 (tiga) makna morfologis, yaitu: mufrad, jamak, dan sifat. Pola kelima fa'alah ( 
mengandung 4 (lima) makna morfologis, yaitu: mufrad, jamak, muannats, dan harf + isim. Pola keenam fu'uul (فُعُوْلَ) mengandung 3 (tiga) makna morfologis, yaitu: mufrad, jamak, dan sifat. Pola ketujuh tafa'ala (تفَّلَ) mengandung 2 (dua) makna morfologis, yaitu: fi'il madhi dan fi'il mudhari. Pola kedelapan

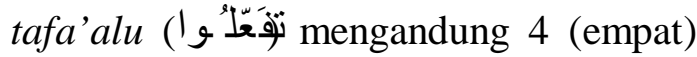
makna morfologis, yaitu: fi'il madhi, fi'mudhari', fi'il amr, dan fi'il nahy. Pola kesembilan af'ala (أفَحَـل) mengandung 5 (empat) makna morfologis, yaitu: fi'il madhi, fi'il mudhari', tafdhil, isim + dhamir dan isim. Terakhir pola kesepuluh fa'ala (فَعَــل) mengandung 5 (lima) makna morfologis, yaitu: fi'il madhi, fi'il mudhari', 'adad', haraf + isim, dan isim + dhamir.

Proses morfofonemis polisemi bahasa Arab dalam Alquran meliputi hadzf, ziyadah, taghyir, tabdil/ibdal, dan ta'lil. Adapun munculnya bentuk polisemik bahasa Arab dalam Alquran adalah karena adanya unsur hadzaf (pelesapan) secara mana suka pada salah satu fonem yang melekat pada fi'il mudhari, seperti (تتصدّىى) dan (تتصدّقو ا) yang dilesapkan ta mudhara'ahnya sehingga bentuknya berubah menjadi

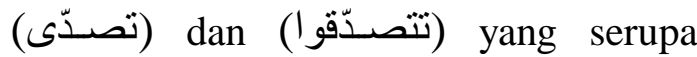
dengan fi'il madhi yang berwazan (تفعَّلَ) dan (تفعّلــوا). Hal ini sebagaimana tercantum dalam firman Allah swt:

$$
\text { فَأَتَتَلَ لُهُ تَصَدَّى (سورة عبس: 6) }
$$

Artinya: Maka kamu melayaninya (QS $80: 6)$.

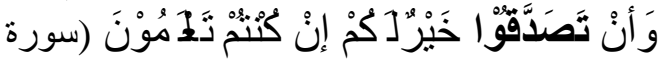

$$
\begin{aligned}
& \text { البقرة: 280) }
\end{aligned}
$$

Artinya: dan menyedekahkan (sebagian atau semua utang) itu, lebih baik bagimu, jika kamu mengetahui (QS 2 : 280).
Jadi, pada shighat (تفعَلْ) terdapat 7 bentuk fi'il mudhari yang serupa wazannya (تفعَلَْ) dengan 22 bentuk fi'il madhi sebagaimana tercantum pada Tabel (nomor 7). Ini karena adanya pelesapan ta mudhara'ah. Adapun pada shighah (تفعَّاو ا) terdapat 3 fi'il mudhari, 12 fi'il madhi, 7 fi'il amr, dan 2 fi'il nahyi, sebagaimana terdapat pada Tabel (nomor 8). Keempat shighat itu sama sewazan (تفعَّو ا) karena adanya pelesapan ta mudhara'ah dan konteks i'rab. Masing-masing, contohnya terdalam firman Allah swt:

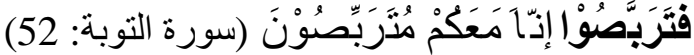
Artinya: sebab itu tunggulah, sesungguhnya kami menunggu-nunggu bersamamu QS 9 : 52).

$$
\text { تَنَكَرُوْواف فَإذاَ هُمْ مُنْصِرُوْنَ (سورة الأعراف: }
$$

Artinya:. mereka ingat kepada Allah, maka ketika itu juga mereka melihat kesalahan-kesalahannya (QS 7 : 201).

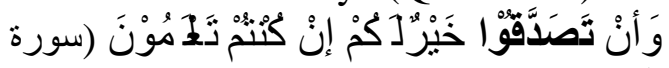

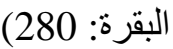

Artinya: dan menyedekahkan (sebagian atau semua utang) itu, lebih baik bagimu, jika kamu mengetahui (QS 2 : 280).

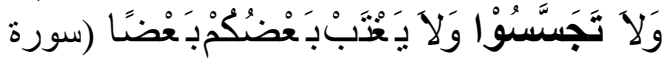

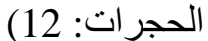

Artinya: dan janganlah mencari-cari keburukan orang dan janganlah menggunjingkan satu sama lain (QS 49 :12). Masing-masing secara berurutan menunjukkan fi'il amr, fi'il madhi, fi'il mudhari, dan fi'il nahyi sesusai dengan konteks i'rab/gramatikal dan leksikalnya masing-masing.

Proses morfologis polisemi bahasa Arab dalam Alquran meliputi morf, morfem, tauzi' sharfy, dan tahlil dakhili lil kalimah. Bentuk-bentuk polisemik dalam bahasa Arab itu bisa muncul karena karakteristik distribusi 
morfolologis bahasa Arab itu sendiri dan makna leksikalnya atau morfo-leksikal selain morfo-gramatikalnya. Misalnya, shighat (فعلة) dan shighat (فعال), masingmasing bisa menunjukkan muannats dari (فعل) dan jamak dari (فاعل), seperti kata (حسنة) yang berasal dari kata (حسن) dan memiliki arti leksikal baik/bagus dan kata (كفرة) yang berasal dari bentuk mufrad (كافر) dan memiliki arti leksikal orang kafir.

Proses morfositaktis polisemi bahasa Arab dalam Alquran meliputi tauzi' sharfy, tauzi' tarkibiy, tarkib idhafi, dan tarkib 'adadi. Munculnya bentuk polisemik bahasa Arab dalam Alquran karena diterapakannya tauzi' sharfi-tarkiby/nahwi, seperti shighat mufrad (فعول) sama bentuknya dengan shighat jamak (فعول) sebagaimana terdapat pada Tabel (nomor 6). Ada 22 shighat mufrad dan 51 shighat jamak, kedua shighat itu sama wazannya (فعول). Misalnya terdapat dalam firman Allah swt:

$$
\text { وَمَا يَزيْدُهُهُ إلاَحَقُوْراً (سورة الإسراء: }
$$

Artinya: dan ulangan peringatan itu tidak lain hanyalah menambah mereka lari (dari kebenaran(QS 17 : 41).

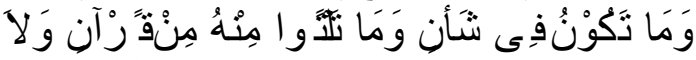

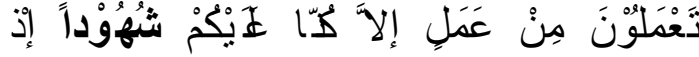

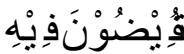

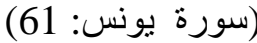

Artinya: kamu tidak berada dalam suatu keadaan dan tidak membaca suatu ayat dari Al Quran dan kamu tidak mengerjakan suatu pekerjaan, melainkan Kami menjadi saksi atasmu di waktu kamu melakukannya (QS 10: 61).

Kata (نفور ا) menunjukkan shigat mufrad yang berasal dari fi'il madhi (نفر) yang makna leksikalnya adalah lari, sedangkan kata (شهودا) menunjukkan shighat jamak dari kata (شاهد) sebagai isim fa'il dari fi'il madhi tsulatsi mujarrad (شهُ) yang makna leksikalnya adalah saksi.

Kemudian bentuk polisemik (أفحلَ) itu bisa muncul karena tarkib idhafi yang tersusun dari isim dan dhamir dalam keadaan manshub sebagai maf'ul bih, seperti kata (أهلأك) yang maknanya keluargamu bisa sama bentuknya dengan fi'il madhi (أهلأ) tsulatsi mazid yang secara leksikal berarti membinasakan. Demikian pula dengan bentuk polisemik (فعل) bisa muncul karena tarkib nahwi yang tersusun dari lam taukid/ibtida dan dharaf makan, seperti (لمع) yang berarti sungguh beserta, itu bisa sama sepola dengan fi'il madhi tsulatsi mujarrad (لمع) yang berarti mengkilat/bersinar. Selain itu bentuk polisemik ini bisa mengandung makna 'adad murakkab (numeralia padu), seperti (أحد) pada tarkib (أحد عشر) yang artinya sebelas.

Variasi makna leksikal polisemi bahasa Arab dalam Alquran adalah setiap polisemi memiliki lebih dari satu makna leksikal sesuai dengan konteksnya. Rata-rata tingkat variasi makna leksikal di atas adalah $\mathbf{6 1 , 3 8 \%}$. Setiap bentuk polisemik itu memiliki variasi leksikal dan variasi gramatikal, kecuali bentuk polisemik nomor 8 tidak memiliki variasi gramatikal dalam bahasa Indonesia terjemahannya.

Contoh variasi leksikal (bentuk polisemik nomor 1) mencakup repetisi, sinonimi, polisemi, dan gramatika: pembawa berita gembira (2x); pembawa khabar gembira (2x) ( بشير); kisah = cerita (حديث); teman - air yang panas akrab (حميم) dan variasi gramatikal: terpercaya - dipercaya - dapat dipercaya - kepercayaan (أمين). 
Contoh variasi leksikal (bentuk polisemik nomor 2) mencakup repetisi, sinonimi, polisemi, dan gramatika: sebagai atap $(2 \mathrm{x})=(ب \mathrm{~s})$; tabir $(2 \mathrm{x})=$ (حجاب); $\quad$ kawin = nikah (نكاح); pertemuan = perjumpaan (لقاء); makhluk - hamba-hamba (عباد) dan variasi gramatikal: ke kiri - dari kiri (شمال).

Contoh variasi leksikal (bentuk polisemik nomor 3) mencakup repetisi, sinonimi, polisemi, dan gramatika: berhala-berhala $(2 x)=($ أوثان); keterangan $(2 x)=($ (اللوان) macam = warna kesesatan = kedurhakaan (طغيان); muka - dagu (أذقان) dan variasi gramatikal: telinga - telinga-telinga (أذن).

Contoh variasi leksikal (bentuk polisemik nomor 4) mencakup repetisi, sinonimi, polisemi, dan gramatika: jalanjalan (2x) (سبل); tempat tinggal (3x) (نز), utusan- utusan = rasul-rasul (رسل); (رزو) (هز); dekat - junub - jauh (جنب) dan variasi gramatikal: yang baik - kebaikan (حسنة).

Contoh variasi leksikal (bentuk polisemik nomor 5) mencakup repetisi, sinonimi, polisemi, dan gramatika: penjaga-penjaga $(2 \mathrm{x})=(ر)$ (رقبة); hamba sahaya $(2 \mathrm{x})=(ر)$ ); satu tingkatan = satu derajat (درجة); hamba sahaya = seorang budak (رقبة); (tidak ada polisemi) dan variasi gramatikal: beberapa ahli shir - ahli-ahli sihir (سحرة).

Contoh variasi leksikal (bentuk polisemik nomor 6) mencakup repetisi, sinonimi, polisemi, dan gramatika:

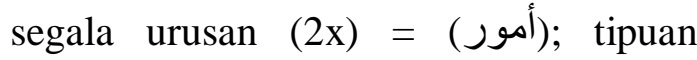

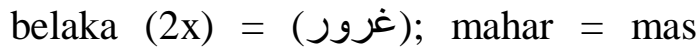
kawin (أجور); para-paranya = atapatapnya (عروش); pokok - kepala dan dariasi gramatikal: kebangkitan - dibangkitkan (نشور ).

Contoh variasi leksikal (bentuk polisemik nomor 7) mencakup repetisi, sinonimi, polisemi, dan gramatika: tidak ada repetis pada makna leksikal shighat (تفعّل); $\quad$ nyata = jelas (تبيّن); memberitahukan = mema'lumkan (تأنَن) (تَّن); kembali - berpaling - berkawan (تون); (تّى); dan variasi gramatikal: bersih membersihkan diri (تزكى).

Contoh variasi leksikal (bentuk polisemik nomor 8) mencakup repetisi, sinonimi, polisemi, dan gramatika: tunggulah $(4 \mathrm{x})$, tunggulah $=$ nantikanlah (تربّصوا); telitilah = periksalah (تبيّنوا); memilih - bertayamum (تيمّموا) dan variasi gramatikal: tidak terdapat variasi gramatikal dalam bahasa Indonesia terjemahannya untuk shighat (تفعّلو ا).

Contoh variasi leksikal (bentuk polisemik nomor 9) mencakup repetisi, sinonimi, polisemi, dan gramatika: yang paling baik $(2 \mathrm{x})=(ا ٔ ح س ن) ; ~ m e m b e r$ manfaat (أغنى); berguna = berfaedah (أغنى); memancarkan = mengeluarkan (أخرج); mengucapkan - melemparkan memasukkan - menggunakan mengemukakan (ألقى) dan variasi gramatikal: yang baik - yang lebih baik - yang paling baik (أحسن).

Contoh variasi leksikal (bentuk polisemik nomor 10) mencakup repetisi, sinonimi, polisemi, dan gramatika: menyuruh $(2 x)=(ا ٔ م ر)$; meninggalkan $(2 x)=(ت ر ك)$; ditetapkan = ditentukan (كتب); kisah = berita (نبأ); mengambil mengazab - mencabut - mengeluarkan (أخذ) dan variasi gramatikal: mengutus diutus (بعث).

Selanjutnya Variasi makna leksikal polisemi bahasa Arab dalam Alquran adalah setiap polisemi memiliki 
lebih dari satu makna leksikal/gramatikal sesuai dengan konteksnya. Variasi makna leksikal mencakup takrar (pengulangan), taraduf (sinonimi), dan isytirak (polisemi). Pada variasi polisemi terdapat kata-kata yang frekuensi kemunculan sangat banyak, tetapi tidak atau kurang bervariasi makna leksikal/gramatikalnya dalam bahasa Indonesia terjemahannya dan sebaliknya, terutama kata-kata yang berkaitan dengan sifat Tuhan, seperti (عليم) hanya memiliki makna leksikal: Mengetahui/Maha Mengetahui dan (رحش) juga hanya memiliki makna leksikal Penyayang/Maha Penyayang; kedua kata ini yang berkelas kata sifat (adjektiva) yang memiliki frekuensi masing-masing sebanyak 106 kali dan 81 kali muncul dalam bahasa Indonesia terjemahan Alquran.

Lebih lanjut dapat dikatakan bahwa variasi makna leksikal/gramatkal yang mencakup repetisi, sinonimi, polisemi, dan gramatika sebagai hasil terjemahan dari 10 (sepuluh) bentuk polisemik bahasa Arab, ini berarti bahwa penerjemah Alquran telah menggunakan relasi makna yang bervariasi dalam menerjemahkan bentuk-bentuk polisemik bahasa Arab dalam Alquran ke dalam bahasa Indonesia, khususnya sinonimi dan polisemi. Sinonimi berarti hubungan semantik yang menyatakan adanya kesamaan makna antara satuan ujuaran dengan satuan ujaran lainnya. Misalnya antara kata betul dan kata benar (Chaer, 2012: 297). Adapun polisemi adalah kata yang mempunyai makna lebih dari satu, seperti kata kepala yang mempunyai makna (1) bagian tubuh manusia dan (2) ketua atau pemimpin (Chaer, 2012: 301).

Adapun Implikasinya bagi pembelajaran gramatika bahasa Arab, terjemah, dan insya (mengarang) meliputi materi (bahan), metode pembelajaran, dan evaluasi proses dan hasil pembelajarannya.

Dari segi materi, pembelajaran gramatika bahasa Arab, terjemah, dan insya perlu diperhatikan gradasinya dan frekuensinya serta variasi makna leksikalnya. Dari segi metode, perlu digunakan metode analisis kontrastif dengan menyajikan dua contoh antara bahasa ibu dan bahasa sasaran serta menggunakan metode gabungan antara metode struktural dan metode tradisional dengan menekankan penerapan tata bahasa fungsional-leksikal, yaitu gabungan antara metode gramatikal dan pendekatan leksikal. Adapun dari segi evaluasi, di samping aspek kognitif mahasiswa, perlu juga diperhatikan aspek afektifnya (minat dan motivasi), khususnya terhadap mata kuliah gramatika, terjemah, dan insya yang sangat erat kaitannya dengan proses dan kualitas penulisan skripsi mahasiswa Jurusan Pendidikan Bahasa Arab FPBS UPI pada khususnya.

\section{SIMPULAN DAN SARAN}

Berdasarkan hasil penelitian dan pembahasan pada bagian terdahulu, dapat disimpulkan beberapa hal di bawah ini.

1. Wazan (pola) polisemi bahasa Arab dalam Alquran meliputi (فَعَدن),

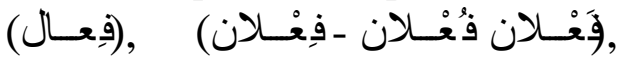

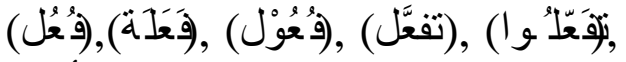

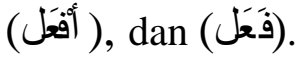

Pola pertama fa'il (فُعَل) mengandung 4 (empat) makna morfologis, yaitu: sifat, isim, jamak,

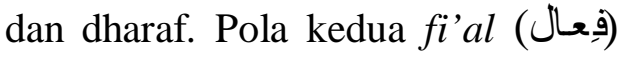
mengandung 3 (tiga) makna morfolosis, yaitu: mufrad, jamak, dan sifat. Pola ketiga fa'lan/fi'lan/fu'lan ( - 


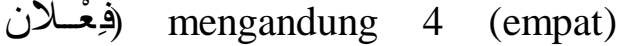
makna morfologis, yaitu: mufrad, mutsanna, jamak, dan sifat. Pola keempat fu'ul (فُ وُعل) mengandung 3 (tiga) makna morfologis, yaitu: mufrad, jamak, dan sifat. Pola kelima fa'alah (aَ) (lima) makna morfologis, yaitu: mufrad, jamak, muannats, dan harf + isim. Pola keenam fu'uul (فُعُوْل mengandung 3 (tiga) makna morfologis, yaitu: mufrad, jamak, dan sifat. Pola ketujuh tafa'ala (تفعَّلى) mengandung 2 (dua) makna morfologis, yaitu: fi'il madhi dan fi'il mudhari. Pola kedelapan

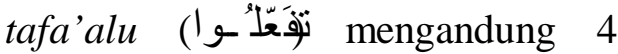
(empat) makna morfologis, yaitu: fi'il madhi, fi'mudhari', fi'il amr, dan fi'il nahy. Pola kesembilan af'ala (أفَفَلْ ) mengandung 5 (empat) makna morfologis, yaitu: fi'il madhi, fi'il mudhari', tafdhil, isim + dhamir dan isim. Terakhir pola kesepuluh fa'ala (فَعَ) mengandung 5 (lima) makna morfologis, yaitu: fi'il madhi, fi'il mudhari', 'adad', haraf + isim, dan isim + dhamir.

2. Munculnya bentuk polisemik bahasa Arab dalam Alquran adalah karena proses morfofonemis, antara lain penerapan hadzf (pelesapan) ta mudhara'ah yang melekat pada fi'il mudhari.

3. Proses morfologis bahasa Arab dalam Alquran yang menyebabkan munculnya bentuk polisemik, antara lain, berkaitan dengan pemakaian distribusi morfologis tentang bentukan kata itu sendiri yang mangandung makna leksikal tertentu.

4. Proses morfosintaktis polisemi bahasa Arab dalam Alquran meliputi tauzi' sharfy- tarkiby, tarkib idhafi, dan tarkib 'adadi.

5. Pada umumnya $(61,38 \%)$, bentuk polisemik bahasa Arab dalam Alquran memiliki tingkat variasi leksikal/gramatikal yang mencakup repetitif $(33,83 \%), \quad$ sinonim $(11,11 \%)$, polisemik $(6,80 \%)$, dan gramatikal $(9,50)$. Selain itu, ada 2 (dua) bentuk polisemik, yaitu:

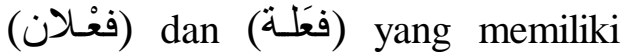
tingkat variasi leksikal/gramatikal dalam kategori tinggi $(77,78 \%)$ dan $(72,00 \%)$; yang lainnya 4 (empat) bentuk polisemik bahasa Arab, yaitu: (فَعِيـل) (فَعَلَ), (فَلَ), dan (فُعـول) memiliki tingkat variasi leksikal/gramatikal dalam kategori sedang (masing-masing secara berurutan: $(63,81 \%), \quad(66,04 \%)$, $68,52 \%)$, dan $(69,87 \%)$.

Di samping itu, dalam bentuk polisemik (فِيـل bahasa Arab terdapat 2 kata yang frekuensi kemunculannya sangat banyak (106x dan $81 x)$, tetapi tidak atau kurang bervariasi makna leksikal/gramatikalnya dalam bahasa Indonesia terjemahannya dan sebaliknya, yaitu kata (عليم) yang memiliki makna leksikal: Mengetahui/Maha Mengetahui dan (رحــ) yang memiliki makna leksikal Penyayang/Maha Penyayang.

6. Hasil penelitian ini berimplikasi pada pengembangan perkuliahan qawaid, tarjamah, dan insya yang mencakup segi materi, metode, dan evaluasinya. Materi kuliah perlu diperhatikan gradasinya dan frekuensinya serta variasi makna leksikal-gramatikalnya. Perlu digunakan metode analisis kontrastif dan metode gabungan antara metode 
struktural dan metode tradisional dengan menekankan penerapan tata bahasa fungsional-leksikal, yaitu gabungan antara metode gramatikal dan pendekatan leksikal. Selain itu perlu kembangkan alat evaluasi keempat mata kuliah tadi yang mencakup polisemi bahasa Arab baik bantuk maupun makna leksikalnya.

Berkaitan dengan kesimpulan penelitian ini, perlu dikemukakan beberapa saran berikut.

1. Untuk menghidari kesalahan atau kekeliruan morfologis dalam membaca dan atau menerjemahkan teks bahasa Arab, khususnya di kalangan mahasiswa Jurusan Pendidikan Bahasa Arab FPBS UPI, mereka hendaknya diberi latihan secukupnya dalam menerapkan pengetahuan teoretisnya tentang morfo-leksikal bahasa Arab yang dikaitkan secara simultan dengan pengetahuan sintaksis dan kosakata atau makna leksikalnya. Dengan kata lain kaidah-kaidah morfologi dan sintaksis bahasa Arab (morfosintaksis) hendaknya dijelaskan dan diterapkan langsung dalam distribusi sintaktis serta dikaitkan dengan makna leksikal sehingga mereka memiliki pengetahuan praktis dan kemampuan aplikatif tentang makna gramatikal dan makna leksikal secara terpadu.

2. Salah satu upaya untuk mengatasi kesulitan morfologis yang berkaitan dengan pemakaian fenomena bentuk polisemik bahasa Arab, perlu diupayakan pembelajaran gramatika (morfo-sintaksis bahasa Arab) melalui pendekatan/terpadu antara mazhab tradisional mazhab struktural dan penerapan gramatika fungsional-leksikal, yaitu metode yang memadukan gramatika dengan kosakata secara simultan.

3. Hasil penelitian ini masih perlu dikaji lebih lanjut dengan memadukan aspek-aspek morfologi dan aspek-aspek sintaksis serta makna leksikal bahasa Arab dalam Alquran melalui kajian tafsir kebahasaraban.

\section{UCAPAN TERIMA KASIH}

Peneliti mengucapkan terima kasih kepada semua pihak, khususnya kepada LPPM UPI, Dekan FPBS, dan Redaksi Jurnal Bahasa \& Sastra yang telah membantu mereviu tulisan artikel penelitian ini hingga pemuatannya.

\section{PUSTAKA RUJUKAN}

Chaer, Abdul. 2012. Linguistik Umum. Jakarta: Rineka Cipta.

Depag. 1990. Alquran dan Terjemahnya. Jakarta: LPMA.

Hanna, Sami Ayyad. 1997. Mu'jam alLisaniyyat al-Haditsah. Beirut: Maktabah Lubnan.

Hasanain, Shalahuddin Shalih. 1984. Dirasaat fii Ilmil Lughah. Riyad: Darul Uluum.

Hassan, Tammam.1979. Al-Lughah al'Arabiyyah: Ma'naahaa wa Mabnaahaa. Kairo: Mathabi' alHaiah al-Mishriyyah al-Ammah li al-Kuttaab.

Katsir, Ibnu. 774 H. Tafsir Al-Qur'an alKarim. Syirkah al-Nur Asia.

Mubarak, Muhammad.1960. Fiqhul Lughah wa Khashaish al'Arabiyyah. Damsyik: Dar alFikr. 
bahasa \& sastra, Vol. 14, No.1, April 2014

Syahin, Abd al-Shabur. 1980. Fi 'Ilmil

Lughah al-'Aam. Berut:

Muassasah al-

Risalah. 